\title{
Microsymposia
}

Aqueous routes used for the synthesis of nanoscale particles of $\mathrm{LiFePO}_{4}$ may lead, under specific conditions, to a full solid solution behavior upon $\mathrm{Li}^{+}$extraction at ambient temperature, hence favoring an easier monitoring of the state of charge/discharge of the electrode [1]. We demonstrated through neutron diffraction that this behavior is strongly connected with the presence of significant amounts of structural defects within the crystallites ( $\mathrm{Li} \Leftrightarrow \mathrm{Fe}$ exchange, vacancies) [2]. We demonstrated as well that it was possible to monitor and adjust the amount of structural defects through careful annealing in air between $140^{\circ} \mathrm{C}$ and $500^{\circ} \mathrm{C}$, up to a composition close to $\mathrm{LiFe}_{0.67} \mathrm{PO}_{4}$ [3]. An important feature is that these findings suggest unusually high mobility of Fe within the triphylite framework

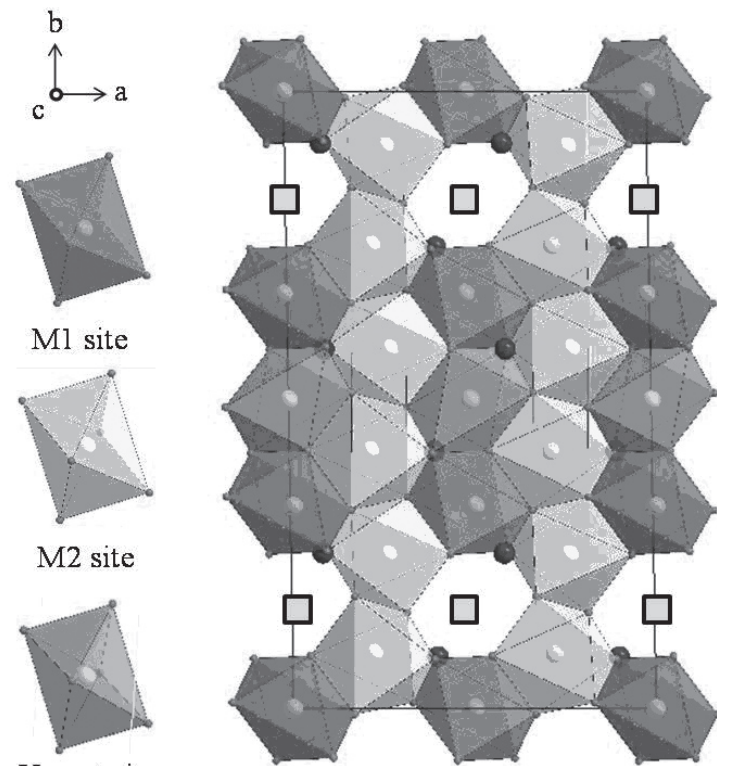

Figure 1: Proposed model for the superstructure of $\mathrm{LiFe}_{2 / 3} \mathrm{PO}_{4}$ built by analogy with the structure of laihunite $\mathrm{Fe}_{2-x} \mathrm{SiO}_{4}$

The resulting powders show complete new electrochemical features (fig. 1) at various redox steps between $3.5 \mathrm{~V}$ and $2.8 \mathrm{~V}$ vs Li, associated with partial redistribution of $\mathrm{Fe}$ and $\mathrm{Li}$ within the octahedral sites, followed by in situ Mossbauer spectroscopy and X-ray diffraction. New crystal super-structures [4] with long range ordering of Fe, vacancies and/or Li (fig. 2), determined through electron diffraction and high resolution Synchrotron X-Ray and neutron diffraction will be presented.

[1] F. Mestre-Aizpurua, S. Hamelet, C. Masquelier, R. Palacin, J. Power Sources 2010, 195(19), 6897-6901. [2] P. Gibot, M. Casas-Cabanas, L. Laffont, S. Levasseur, P. Carlach, S. Hamelet, J-M. Tarascon, C. Masquelier, Nature Materials 2008, 7, 741-747. [3] S. Hamelet, P. Gibot, M. Casas Cabanas, D. Bonnin, C. Grey, J. Cabana, J.B. Leriche, J. Rodriguez Carvajal, M. Courty, S. Levasseur, P. Carlach, M. Van Thournout, J.M. Tarascon, C. Masquelier ; J. Mater. Chem. 2009, 19, 3979-3991. [4] S. Hamelet, M. Casas Cabanas, L. Dupont, C. Davoisne, J.M. Tarascon, C. Masquelier, Chem. Mater. 2011, 23, 32-38.

Keywords: battery materials, phosphates, diffraction
Uruguay. ${ }^{\mathrm{b}}$ Physics Department, Northern Illinois University, DeKalb, IL 60115, (USA). E-mail: leopoldo@fq.edu.uy

Perovskite manganites have been extensively studied during last several decades due to a wide range of functional properties like colossal magnetoresistance, mixed ionic-electronic conductivity, and large magnetocaloric effect. Additionally oxygen deficient manganites are relevant as Solid Oxide Fuel Cell cathode materials.

During a systematic study of structural aspects of oxygen deficient $\mathrm{La}_{\mathrm{x}} \mathrm{Sr}_{1-\mathrm{x}} \mathrm{MnO}_{3-\delta}$ compounds we determined the structure of a new compound $\mathrm{Sr}_{7} \mathrm{Mn}_{7} \mathrm{O}_{19}\left(\mathrm{SrMnO}_{2.714}\right)$ [1] showing a new oxygen vacancy ordering arrangement. We also found that the previously described vacancy ordered phases $\mathrm{Sr}_{2} \mathrm{Mn}_{2} \mathrm{O}_{5}\left(\mathrm{SrMnO}_{2.5}\right), \mathrm{Sr}_{5} \mathrm{Mn}_{5} \mathrm{O}_{13}$ $\left(\mathrm{SrMnO}_{26}\right)$ and the new phase form a new homologous series of compounds with general formula $\mathrm{Sr}_{4+\mathrm{n}} \mathrm{Mn}^{3+}{ }_{4} \mathrm{Mn}^{4+}{ }_{\mathrm{n}} \mathrm{O}_{10-3 \mathrm{n}}$ that in certain conditions may accept La substitution [2] and may also be extended to well-known compounds in the $\mathrm{CaMnO}_{3-\delta}, \mathrm{LaCuO}_{3-\delta}$ and $\mathrm{NdCuO}_{3-\delta}$ series $[3,4,5]$.

Starting with the $\mathrm{n}=0$ member of the series $\left(\mathrm{Sr}_{4} \mathrm{Mn}_{4} \mathrm{O}_{10}\right)$, containing pyramidal Jahn-Teller $\mathrm{Mn}^{3+}$ cations, a basic building block for the homologous series is built based on four pyramids lying on the 001 plane with the apex of the pyramids pointing alternatively in the in the [100], [010], [0-10] and [-100] directions in a $\mathrm{p}_{\mathrm{x}} \mathrm{p}_{\mathrm{y}} \mathrm{p}_{-\mathrm{y}} \mathrm{p}_{-\mathrm{x}}$ arrangement. This arrangement repeats in the normal direction of the plane replacing $\mathrm{x}$ by $\mathrm{y}$ and viceversa. The $\mathrm{n}^{\text {th }}$ member of the series is built by adding $\mathrm{n}$ $\mathrm{Mn}^{4+}$ octahedra to the four pyramids keeping the order of the pyramids and the $2 / \mathrm{m}$ symmetry of the original block. The $\mathrm{n}=1$ member $\mathrm{Sr}_{5} \mathrm{Mn}_{5} \mathrm{O}_{13}$ is formed with the building block $\mathrm{p}_{\mathrm{x}} \mathrm{p}_{\mathrm{y}} \mathrm{Op} \mathrm{p}_{-\mathrm{y}} \mathrm{p}_{-\mathrm{x}}$ while the $\mathrm{n}=3$ member

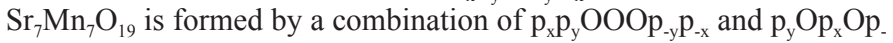
${ }_{\mathrm{x}} \mathrm{Op}_{-\mathrm{y}}$ blocks in the $\mathrm{x}$ and $\mathrm{y}$ direction. The $\mathrm{n}=0$ and 1 members of the series are also found in $\mathrm{LaCuO}_{3-\delta}$ and $\mathrm{NdCuO}_{3-\delta}$ systems, while only $\mathrm{n}=0$ members are found for $\mathrm{SrCuO}_{3-\delta}$ and $\mathrm{CaMnO}_{3-\delta}$ systems, although many stable compounds with stoichiometries compatible with $\mathrm{n}=2$ and 4 have been studied in this latter system.

The lack of observation of $\mathrm{n}=2$ and 4 members of the $\mathrm{Sr}_{4+\mathrm{n}} \mathrm{Mn}^{3+}{ }_{4} \mathrm{Mnn}^{4+} \mathrm{O}_{10-3 \mathrm{n}}$ series is supposed to be related to the geometrical incompatibility among the two possible $\mathrm{p}_{\mathrm{x}} \mathrm{p}_{\mathrm{y}} \mathrm{OOp_{-y }} \mathrm{p}_{-\mathrm{x}}$ and $\mathrm{p}_{\mathrm{x}} \mathrm{O} \mathrm{p}_{\mathrm{y}} \mathrm{p}_{-\mathrm{y}} \mathrm{O} \mathrm{p}_{-\mathrm{x}}$ building blocks (different from the combination of them in $n=3$ member) and the reduction of stability of structures where two pyramids are linked by the apical oxygen resulting from these blocks. Additionally, A cation size seems to correlate with the lack of observation of other members of the series in the $\mathrm{CaMnO}_{3-\delta}$ system.
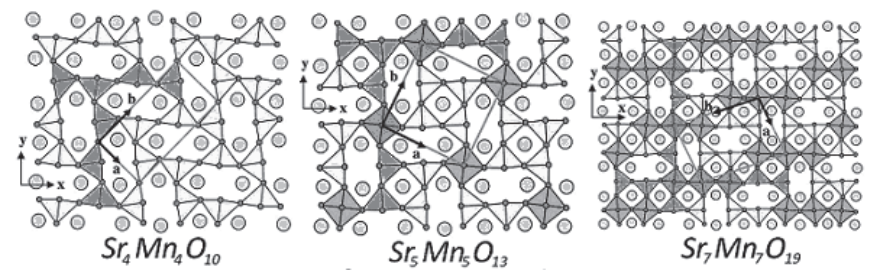

[1] L. Suescun et al. J. Solid State Chem. 2007, 180, 1698. [2] L. Suescun et al. Chem. Mater. 2008, 20,1636. [3] A. Reller, et al. J. Chem. Soc. Chem. Commun.1980, 1378; J. F. Bringley, et al. Nature (London), 1990, 374, 263; B.-H. Chen, et al. Inorg. Chem. 1995, 34, 2077.

Keywords: homologous_series, manganites, perovskites

MS.39.4

Acta Cryst. (2011) A67, C96
A new homologous series of oxygen vacancy ordered strontium manganese perovskite

Leopoldo Suescun, ${ }^{\text {a }}$ Bogdan Dabrowski, ${ }^{\text {a }}$ Cryssmat-Lab/DETEMA, Facultad de Química, Universidad de la República, Montevideo,

\section{Polyene-diphenylaniline D5 dyes and their role in the efficiency of} DSSC solar cells

D. Viterbo, ${ }^{\text {a }}$ E. Artuso, ${ }^{\mathrm{b}}$ C. Barolo, ${ }^{\mathrm{b}}$ G. Croce,${ }^{\mathrm{a}}$ L. Palin, ${ }^{\mathrm{a}}$ W. Van beek, ${ }^{\mathrm{a}, \mathrm{c}} \mathrm{V}$. Gianotti, ${ }^{\mathrm{d}} \mathrm{M}$. Milanesio, ${ }^{\mathrm{a}} \quad{ }^{a}$ DISTA and ${ }^{d} D I S A V$ - Università 